Т. Г. Озерникова

Байкальский государственный университет, г. Иркутск, Российская Федерация

Д. А. Еловенко

Иркутский национальный исследовательский технический университет, 2. Иркутск, Российская Федерация

\title{
ПРОБЛЕМЫ ВНЕДРЕНИЯ ПРОФЕССИОНАЛЬНОГО СТАНДАРТА В СИСТЕМУ УПРАВЛЕНИЯ ТРУДОВОЙ ДЕЯТЕЛЬНОСТЬЮ ПРОФЕССОРСКО-ПРЕПОДАВАТЕЛЬСКОГО СОСТАВА ВУЗОВ
}

\begin{abstract}
АНнотАция. Приведены результаты исследования содержания профессионального стандарта педагога и проблем его практического внедрения в государственных вузах. Определены отличия структуры и содержания профессионального стандарта от Единого квалификационного справочника должностей руководителей, специалистов и служащих, в контексте определения квалификационных требований. Выявлены проблемы внедрения основных элементов профессионального стандарта педагога: квалификационных требований, описания трудовых функций и описания необходимых знаний и умений. Определены факторы нормативного, методического и организационного характера, препятствующие немедленному переходу к профессиональному стандарту педагога в государственных вузах. Сделан вывод о невозможности полного внедрения профессионального стандарта педагога без серьезной правовой, организационной и методической проработки.
\end{abstract}

кЛюЧЕВЫЕ СлОВА. Профессиональный стандарт педагога; профессорско-преподавательский состав; проблемы внедрения.

ИНФОРМАЦИЯ О СТАТЬЕ. Дата поступления 13 апреля 2017 г.; дата принятия к печати 19 мая 2017 г.; дата онлайн-размещения 23 июня 2017 г.

T. G. Ozernikova Baikal State University, Irkutsk, Russian Federation

D. A. Elovenko

Irkutsk National Research Technical University, Irkutsk, Russian Federation

\section{PROBLEMS OF INTRODUCING THE PROFESSIONAL STANDARD IN THE LABOR ACTIVITY SYSTEM FOR UNIVERSITY FACULTY MEMBERS}

ABSTRACT. The Article brings forth the results of investigating the content of the professional standard of the conveyor of knowledge and the problems of its practical implementation in state universities. It determines the differences in the structure and content of the professional standard from the Unified Qualification Reference Book for positions of administrators, specialists and employees in the context of qualification requirement specification. It identifies the problems of introducing the major elements of the professional standard of the conveyor of knowledge: qualification requirements, description of labor functions and description of necessary knowledge and skills. It determines the factors of normative, methodical and organizational character that prevent immediate transition to the professional standard of the conveyor of knowledge in state universities. A conclusion is drawn about impossibility of complete introduction of the professional standard of the conveyor of knowledge without serious legal, organizational and methodical consideration.

\section{Baikal Research Journal}


KEYWORDS. Professional standard of the conveyor of knowledge; faculty members; the problems of introduction.

ARTICLE INFO. Received April 13, 2017; accepted May 19, 2017; available online June 23, 2017.

В условиях перехода к информационному типу развития экономики происходит трансформация сферы занятости, существенно изменяются профессиональные качества, востребованные на рынке труда. «Для работодателя становится ценнее не квалификация как таковая, а компетентность, характеризующаяся обладанием определенными способностями для решения конкретных задач» [1, с. 68]. Все в большей степени ощущается необходимость глубокой и тесной взаимосвязи, координации сферы труда и сферы профессионального образования. Соответственно, закономерна трансформация старой, сложившейся еще в советское время системы квалификаций на основе разработки и внедрения профессиональных стандартов. В период с 1998 по 2004 г. Институт труда и социального страхования Министерства труда и социального развития Российской Федерации осуществил ряд проектов по разработке профессиональных стандартов. В 2001 г. после принятия нового Трудового кодекса РФ была сформулирована необходимость разработки взамен Единого тарифно-квалификационного справочника работ и профессий рабочих (ETKC) и Единого квалификационного справочника должностей руководителей, специалистов и служащих (ЕКС) нового типа документа для применения в организациях любой формы собственности. Значимый вклад в разработку профессиональных стандартов внес Российский союз промышленников и предпринимателей (РСПП), предложивший макет профессионального стандарта на основе передового зарубежного опыта. В то же время, предложения РСПП не имели нормативно-правового закрепления, что существенно снижало возможности их практического использования [2].

В августе 2010 г. на совместном заседании Государственного совета Российской Федерации и Комиссии по модернизации и технологическому развитию экономики РФ, посвященном развитию профессионального образования, президент Д. А. Медведев заявил о необходимости создания в России системы профессиональных стандартов. Указом Президента Российской Федерации «О мероприятиях по реализации государственной социальной политики» от 7 мая 2012 г. № 597 поставлены задачи утвердить до 1 декабря 2012 г. план разработки профессиональных стандартов, разработать к 2015 г. и утвердить не менее 800 профессиональных стандартов. План разработки профессиональных стандартов на 2012-2015 гг. опубликован на сайте Института труда и социального страхования Минтруда РФ.

По своему функциональному назначению профессиональный стандарт служит отражением нормативных требований к уровню квалификации рабочей силы в различных профессиональных сферах [1, с. 69-70]. Профессиональный стандарт - это новый для работодателей инструмент решения задач в области управления персоналом. В частности, он может быть применен при разработке должностных инструкций, тарификации должностей, подборе и аттестации персонала, при планировании обучения и карьеры. Для работников профессиональный стандарт обеспечивает возможности сформировать навыки, необходимые для решения производственных задач [3]. Для образовательных организаций профессиональные стандарты служат ориентиром при разработке профессиональных образовательных программ.

Эта новая реальность порождает множество исследовательских и практических проблем. Активно обсуждаются вопросы обязательности внедрения профессиональных стандартов в практику управления персоналом негосударственных

\section{Baikal Research Journal}

электронный научный журнал Байкальского государственного университета 
организаций. Важная проблема, требующая пристального внимания и изучения - это переход к ФГОС ВО $3++$, разрабатываемых с учетом требований профессиональных стандартов и впервые предоставляющих возможность прямой интеграции результатов обучения и требований работодателей. Активно обсуждается в научном сообществе роль профессионального стандарта педагога в совершенствовании образовательных программ в педагогических вузах.

Остановимся на проблеме внедрения профессионального стандарта педагога в систему управления профессорско-преподавательским составом вузов. Несмотря на достаточно узкий масштаб, данная проблема представляется весьма актуальной. Необходимость совершенствования системы управления кадровым потенциалом высшей школы обусловлена рядом причин, главная из которых это решение задачи повышения качества высшего образования в соответствии с потребностями социально-экономического развития общества. Следует отметить, что профессорско-преподавательский состав является непростым объектом управления благодаря исключительно высокой сложности и разнообразию их трудовых функций. Высокие требования к профессорско-преподавательскому составу (ППС) вузов закреплены в Федеральных государственных образовательных стандартах высшего образования (ФГОС ВО).

Профессиональный стандарт преподавателя вуза разрабатывался при участии различных структур, в том числе Минтруда России, Учебно-методического объединения по профессионально-педагогическому образованию (УМО по ППО), ведущих вузов России. Проекты этого документа вызвали активное обсуждение в научном сообществе. Например, анализировались особенности проекта профессионального стандарта «Преподаватель», подготовленного Минтрудом России, и квалификационные требования к должностям научно-педагогических работников высшего образования [4].

Итоговый документ разработан Федеральным институтом развития образования (ФИРО). Профессиональный стандарт «Педагог профессионального обучения, профессионального образования и дополнительного профессионального образования» утвержден приказом Министерства труда и социальной защиты РФ 8 сентября 2015 г. № 608 и применяется, в соответствии с данным приказом, с 1 января 2017 г. при формировании кадровой политики и в управлении персоналом, при организации обучения и аттестации работников, заключении трудовых договоров, разработке должностных инструкций и установлении систем оплаты труда. Необходимость внедрения профессионального стандарта в отношении ППС связывают с переходом от традиционной педагогической системы к системе инновационного образования, от педагога-транслятора знаний к педагогу-новатору, носителю инноваций [5]. Данный профессиональный стандарт называют одним из самых сложных среди более чем 800 профессиональных стандартов, утвержденных к настоящему времени [6, с. 105].

На этапе индустриального развития страны и в условиях командной экономики ЕТКС м ЕКС эффективно выполняли свои функции. В настоящее время справочники не могут обеспечить развитие системы квалификаций, необходимой для развития инновационной экономики в связи с изменением структуры рабочей силы, появлением новых видов трудовой деятельности, а также ужесточением требований работодателей к уровню квалификации работников [1, с. 70]. Профессиональный стандарт отличается от ЕТКС и ЕКС. В ЕТКС приводится описание квалификационных характеристик каждой профессии по каждому разряду, в ЕКС описание каждой должности содержит разделы: должностные обязанности; должен знать; требования к квалификации. Профессиональный стандарт (ПС) построен по иному принципу. Структура ПС включает:

\section{Baikal Research Journal}


- общие сведения (наименование вида профессиональной деятельности, цель вида профессиональной деятельности, отнесение к группе занятий и видам экономической деятельности);

- описание трудовых функций с перечислением обобщенных трудовых функций, уровня квалификации, трудовых функций, их кода и уровня (подуровня) квалификации;

Наиболее объемным и принципиально важным в ПС является выделение и описание обобщенных трудовых функций (ОТФ). ОТФ - это совокупность связанных между собой трудовых функций, имеющих близкий характер, результаты и условия труда. Описание каждой ОТФ включает:

- возможные наименования должностей (профессий), требования к образованию и обучению, требования к опыту практической работы, особые условия допуска к работе. При этом в профессиональных стандартах отражаются минимально необходимые для обеспечения качества труда квалификационные требования [7];

- подробное описание каждой трудовой функции (ТФ), входящей в ОТФ. ТФ понимается как система трудовых действий (ТД) в рамках ОТФ. ТД - процесс взаимодействия работника с предметом труда, при котором достигается определенная задача. По каждой ТФ описаны ТД, необходимые умения и необходимые знания, а также другие характеристики (при необходимости).

Если в ЕКС исходным структурным элементом является должность, которая характеризуется обязанностями, необходимыми знаниями и требованиями к квалификации, то исходной структурной единицей в ПС является ОТФ. Требования к работнику формулируются по ОТФ, требования к знаниям и умениям - по ТФ. Безусловно, профессиональные стандарты более универсальны, так как при их применении в конкретной организации по каждой должности определяется обобщенная трудовая функция (одна или несколько), а в ее рамках - именно те трудовые функции, которые выполняются на конкретном рабочем месте. Соответственно определяются квалификационные требования, а также требования к знаниям и умениям работника. По нашему мнению, применение ПС полезно не только при определении требований к работникам (а значит, совершенствованию отбора и обучения персонала), но и при разработке должностных инструкций, определению ключевых показателей эффективности деятельности работников, оценке и оплате их труда, в том числе и применительно к профессорско-преподавательскому составу вузов.

Содержание профессионального стандарта педагога в целях его постепенного внедрения в отношении ППС вузов может быть разделено на следующие элементы:

1. Квалификационные требования. Именно переход к использованию квалификационных требований к ППС в соответствии с ПС вместо требований ЕКС является наиболее проблемным вопросом с точки зрения сроков перехода. В таблице представлены результаты анализа основных изменений требований к ППС в профессиональном стандарте по сравнению с ЕКС. Главным итогом такого анализа является разработка обоснованного плана мероприятий по обучению и повышению квалификации ППС на основе анализа соответствия кадрового состава ППС вуза требованиям ПС. Проблема повышения квалификации ППС - это одна из наиболее важных в управлении кадровым потенциалом вуза в условиях новых требований к качеству образования, которая активно обсуждается исследователями [8-10]. Внедрение профессионального стандарта педагога дает четкие ориентиры развития системы повышения квалификации преподавателей высшей школы. Так, в ПС нашли отражение требования к владению современными образовательными технологиями [11] и др.

\section{Baikal Research Journal}

электронный научный журнал Байкальского государственного университета 
Основные изленения к квалификационныл требованиял по должностял ППС, предусмотренных в Единол квалификационном справочнике должностей руководителей, специалистов и служащих" и профессиональнол стандарте

«Педагог профессионального обучения, профессионального образования и дополнительного профессионального образования"

\begin{tabular}{|c|c|c|c|c|}
\hline \multirow[t]{2}{*}{ Изменение } & \multirow{2}{*}{$\begin{array}{c}\text { Должности } \\
\text { ППС, которых } \\
\text { касается изме- } \\
\text { нение }\end{array}$} & \multicolumn{2}{|c|}{ Требования } & \multirow{2}{*}{$\begin{array}{c}\text { Необходимые меропри- } \\
\text { ятия для включения в } \\
\text { план-график внедрения } \\
\text { ПС }\end{array}$} \\
\hline & & EKC & $\begin{array}{c}\text { Профессиональный стан- } \\
\text { дарт }\end{array}$ & \\
\hline \multirow[t]{2}{*}{$\begin{array}{l}\text { 1. Уточнение } \\
\text { требований к } \\
\text { уровню обра- } \\
\text { зования по } \\
\text { уровням ВО в } \\
\text { зависимости от } \\
\text { ОТФ и уровня } \\
\text { подготовки }\end{array}$} & \begin{tabular}{|l|} 
Ассистент \\
Преподаватель \\
Старший \\
преподаватель
\end{tabular} & $\begin{array}{l}\text { Высшее профессиональ- } \\
\text { ное образование }\end{array}$ & $\begin{array}{l}\text { Для преподавания - } \\
\text { специалитет и магистра- } \\
\text { тура; для сопровождения } \\
\text { и профориентации - до- } \\
\text { статочно бакалавриата } \\
\text { (те же ТФ могут выпол- } \\
\text { нять преподаватели СПО) }\end{array}$ & \multirow{2}{*}{$\begin{array}{l}\text { По результатам анализа } \\
\text { на соответствие требо- } \\
\text { ваниям - включение в } \\
\text { план мероприятий по по- } \\
\text { вышению квалификации, } \\
\text { ротации и пр. (ограниче- } \\
\text { ние для преподаватель- } \\
\text { ской деятельности по } \\
\text { программам ВО выпуск- } \\
\text { ников бакалавриата) }\end{array}$} \\
\hline & $\begin{array}{l}\text { Доцент } \\
\text { Профессор }\end{array}$ & $\begin{array}{l}\text { Высшее профессиональ- } \\
\text { ное образование }\end{array}$ & $\begin{array}{l}\text { Высшее образование - } \\
\text { специалитет, магистрату- } \\
\text { ра, аспирантура }\end{array}$ & \\
\hline $\begin{array}{l}\text { 2. Появление } \\
\text { требования } \\
\text { профпереподго- } \\
\text { товки }\end{array}$ & \begin{tabular}{|l|} 
Ассистент \\
Преподаватель \\
Старший пре- \\
подаватель \\
Доцент \\
Профессор \\
\end{tabular} & $\begin{array}{l}\text { Данные требования } \\
\text { отсутствуют }\end{array}$ & $\begin{array}{l}\text { ДПО (профпереподготов- } \\
\text { ка) при несоответствии } \\
\text { направленности образо- } \\
\text { вания преподаваемым } \\
\text { дисциплинам }\end{array}$ & $\begin{array}{l}\text { По результатам анализа } \\
\text { на соответствие требо- } \\
\text { ваниям - включение в } \\
\text { план повышения квали- } \\
\text { фикации (в форме пере- } \\
\text { подготовки) }\end{array}$ \\
\hline $\begin{array}{l}\text { 3. Появление } \\
\text { требования } \\
\text { обучения и про- } \\
\text { верки знаний в } \\
\text { области охраны } \\
\text { труда }\end{array}$ & \begin{tabular}{|l|} 
Ассистент \\
Преподаватель \\
Старший \\
преподаватель \\
Доцент \\
Профессор \\
\end{tabular} & $\begin{array}{l}\text { Данные требования } \\
\text { отсутствуют }\end{array}$ & $\begin{array}{l}\text { Обязательное обучение и } \\
\text { проверка знаний в обла- } \\
\text { сти охраны труда }\end{array}$ & $\begin{array}{l}\text { По результатам анализа } \\
\text { на соответствие требо- } \\
\text { ваниям - включение в } \\
\text { план обучения и про- } \\
\text { верки знаний в области } \\
\text { охраны труда } \\
\end{array}$ \\
\hline $\begin{array}{l}\text { 4. Появление } \\
\text { требования } \\
\text { повышения ква- } \\
\text { лификации }\end{array}$ & \begin{tabular}{|l|} 
Ассистент \\
Преподаватель \\
Старший \\
преподаватель \\
Доцент \\
Профессор \\
\end{tabular} & $\begin{array}{l}\text { Данные требования } \\
\text { отсутствуют._Требова- } \\
\text { ния не новые, есть в } \\
\text { ФГОС ВО }\end{array}$ & $\begin{array}{l}\text { Повышение квалифика- } \\
\text { ции не реже, чем раз в } \\
\text { три года }\end{array}$ & $\begin{array}{l}\text { По результатам анализа } \\
\text { на соответствие требо- } \\
\text { ваниям - включение в } \\
\text { план повышения квали- } \\
\text { фикации }\end{array}$ \\
\hline $\begin{array}{l}\text { 5. Появление } \\
\text { раздела «Осо- } \\
\text { бые условия до- } \\
\text { пуска к работе } \\
\text { в соответствии } \\
\text { с законодатель- } \\
\text { ством РФ» }\end{array}$ & \begin{tabular}{|l|} 
Ассистент \\
Преподаватель \\
Старший \\
преподаватель \\
Доцент \\
Профессор
\end{tabular} & $\begin{array}{l}\text { Данные требования } \\
\text { отсутствуют в ЕКС }\end{array}$ & $\begin{array}{l}\text { Отсутствие ограничений } \\
\text { на занятие преподава- } \\
\text { тельской деятельностью, } \\
\text { прохождение обязатель- } \\
\text { ных медицинских осмо- } \\
\text { тров, прохождение атте- } \\
\text { стации на соответствие } \\
\text { занимаемой должности }\end{array}$ & $\begin{array}{l}\text { По результатам анализа } \\
\text { на соответствие требо- } \\
\text { ваниям - разработка } \\
\text { локальных нормативных } \\
\text { актов (внесение измене- } \\
\text { ний в локальные норма- } \\
\text { тивные акты) }\end{array}$ \\
\hline \multirow[t]{2}{*}{$\begin{array}{l}\text { 6. Изменение } \\
\text { требований к } \\
\text { наличию ученой } \\
\text { степени (зва- } \\
\text { ния) }\end{array}$} & Доцент & $\begin{array}{l}\text { Ученая степень канди- } \\
\text { дата (доктора) наук и } \\
\text { стаж научно-педагоги- } \\
\text { ческой работы не менее } \\
3 \text { лет или ученое зва- } \\
\text { ние доцента (старшего } \\
\text { научного сотрудника) } \\
\end{array}$ & $\begin{array}{l}\text { Ученая степень и ученое } \\
\text { звание не обязательны. } \\
\text { При наличии ученого } \\
\text { звания - без предъявле- } \\
\text { ния требований к стажу } \\
\text { работы }\end{array}$ & $\begin{array}{l}\text { Смягчение требований, } \\
\text { ученая степень не обяза- } \\
\text { тельна }\end{array}$ \\
\hline & Профессор & $\begin{array}{l}\text { Ученая степень доктора } \\
\text { наук и стаж научно-пе- } \\
\text { дагогической работы не } \\
\text { менее } 5 \text { лет или ученое } \\
\text { звание профессора }\end{array}$ & $\begin{array}{l}\text { Ученая степень (звание). } \\
\text { Для руководства под- } \\
\text { готовкой аспирантов } \\
\text { по индивидуальному } \\
\text { учебному плану: наличие } \\
\text { публикаций в ведущих } \\
\text { отечественных и (или) }\end{array}$ & $\begin{array}{l}\text { Смягчение требований, } \\
\text { достаточно ученой степе- } \\
\text { ни кандидата наук }\end{array}$ \\
\hline
\end{tabular}

\section{Baikal Research Journal}


Окончание табл.

\begin{tabular}{|c|c|c|c|c|}
\hline \multirow[t]{2}{*}{ Изменение } & \multirow{2}{*}{$\begin{array}{c}\text { Должности } \\
\text { ППС, которых } \\
\text { касается изме- } \\
\text { нение }\end{array}$} & \multicolumn{2}{|c|}{ Требования } & \multirow{2}{*}{$\begin{array}{c}\text { Необходимые меропри- } \\
\text { ятия для включения в } \\
\text { план-график внедрения } \\
\text { ПС }\end{array}$} \\
\hline & & EKC & $\begin{array}{c}\text { Профессиональный стан- } \\
\text { дарт }\end{array}$ & \\
\hline & & & $\begin{array}{l}\text { зарубежных рецензируе- } \\
\text { мых научных журналах } \\
\text { и изданиях и (или) пред- } \\
\text { ставления на националь- } \\
\text { ных и международных } \\
\text { конференциях резуль- } \\
\text { татов научно-исследова- } \\
\text { тельской деятельности, } \\
\text { соответствующей области } \\
\text { исследований аспиранта }\end{array}$ & \\
\hline \multirow[t]{5}{*}{$\begin{array}{l}\text { 7. Изменение } \\
\text { требований к } \\
\text { стажу работы }\end{array}$} & Ассистент & $\begin{array}{l}\text { Стаж работы в образо- } \\
\text { вательном учреждении } \\
\text { не менее } 1 \text { года, при } \\
\text { наличии послевузовско- } \\
\text { го профессионального } \\
\text { образования (аспи- } \\
\text { рантура, ординатура, } \\
\text { адъюнктура) или уче- } \\
\text { ной степени кандидата } \\
\text { наук - без предъяв- } \\
\text { ления требований к } \\
\text { стажу работы }\end{array}$ & $\begin{array}{l}\text { Опыт необходим толь- } \\
\text { ко при несоответствии } \\
\text { направленности образо- } \\
\text { вания преподаваемому } \\
\text { учебному курсу }\end{array}$ & Смягчение требований \\
\hline & Преподаватель & $\begin{array}{l}\text { Стаж работы в образо- } \\
\text { вательном учреждении } \\
\text { не менее } 1 \text { года, при } \\
\text { наличии послевузовско- } \\
\text { го профессионального } \\
\text { образования (аспи- } \\
\text { рантура, ординатура, } \\
\text { адъюнктура) или уче- } \\
\text { ной степени кандидата } \\
\text { наук - без предъяв- } \\
\text { ления требований к } \\
\text { стажу работы }\end{array}$ & $\begin{array}{l}\text { Стаж работы в образова- } \\
\text { тельной организации не } \\
\text { менее одного года, при } \\
\text { наличии ученой степени } \\
\text { (звания) - без предъ- } \\
\text { явления требований к } \\
\text { стажу работы }\end{array}$ & $\begin{array}{l}\text { Требования не измени- } \\
\text { лись }\end{array}$ \\
\hline & $\begin{array}{l}\text { Старший пре- } \\
\text { подаватель }\end{array}$ & $\begin{array}{l}\text { Стаж научно-педагоги- } \\
\text { ческой работы не менее } \\
3 \text { лет, при наличии } \\
\text { ученой степени кан- } \\
\text { дидата наук, стаж } \\
\text { научно-педагогической } \\
\text { работы не менее } 1 \text { года }\end{array}$ & $\begin{array}{l}\text { Стаж научно-педагоги- } \\
\text { ческой работы не менее } \\
\text { трех лет, при наличии } \\
\text { ученой степени (зва- } \\
\text { ния) - без предъявле- } \\
\text { ния требований к стажу } \\
\text { работы }\end{array}$ & $\begin{array}{l}\text { Требования по стажу } \\
\text { остались прежними } \\
(3 \text { года). } \\
\text { Для имеющих ученую } \\
\text { степень (звание) - смяг- } \\
\text { чение требований (без } \\
\text { предъявления требований } \\
\text { к стажу работы) }\end{array}$ \\
\hline & Доцент & $\begin{array}{l}\text { Стаж научно-педагоги- } \\
\text { ческой работы не менее } \\
3 \text { лет при отсутствии } \\
\text { ученого звания доцен- } \\
\text { та (старшего научного } \\
\text { сотрудника) }\end{array}$ & $\begin{array}{l}\text { Стаж научно-педагоги- } \\
\text { ческой работы не менее } \\
\text { трех лет, при наличии } \\
\text { ученого звания - без } \\
\text { предъявления требова- } \\
\text { ний к стажу работы }\end{array}$ & $\begin{array}{l}\text { Требования не измени- } \\
\text { лись }\end{array}$ \\
\hline & Профессор & $\begin{array}{l}\text { Стаж научно-педаго- } \\
\text { гической работы не } \\
\text { менее 5 лет или ученое } \\
\text { звание профессора }\end{array}$ & $\begin{array}{l}\text { Стаж научно-педагоги- } \\
\text { ческой работы не менее } \\
\text { пяти лет }\end{array}$ & $\begin{array}{l}\text { Требования по стажу } \\
\text { остались прежними } \\
\text { (5 лет), в том числе для } \\
\text { имеющих ученое звание } \\
\text { (фактически ужесточение } \\
\text { требований) }\end{array}$ \\
\hline
\end{tabular}

\section{Baikal Research Journal}


Проведенный анализ требований к ППС в двух нормативных документах свидетельствует, что фактически ужесточения требований не произошло. Все новые, по сравнению с ЕКС, требования профессионального стандарта существовали и раньше в других нормативных документах. В этом смысле то, что в рамках профессионального стандарта все эти требования сведены в систему, упрощает работу кадровых подразделений вузов и позволяет системно организовать работу по подбору и планированию обучения ППС. В то же время, смягчение требований по критерию наличия ученой степени по должности доцента и наличия любой ученой степени - по должности профессора противоречит требования ФГОС ВО, а также требованиям ВАК России. Соответственно, переход к профессиональному стандарту требует не только изменений локальных нормативных актов вуза (таких как Положение о конкурсе ППС, Положение об аттестации ППС и др.), но и федеральных нормативных документов.

2. Описание обобщенных трудовых функций и трудовых функций по должностям ППС. Главными ОТФ становятся «Преподавание по программам бакалавриата и ДПП» (должности ассистента, преподавателя, старшего преподавателя) и «Преподавание по программам бакалавриата, специалитета, магистратуры и ДПП» (должность доцента) и «Преподавание по программам аспирантуры (адъюнктуры), ординатуры, ассистентуры-стажировки" (должность профессора). В качестве отдельных ОТФ выделены «Организационно-педагогическое сопровождение группы (курса) обучающихся по программам ВО» и «Проведение профориентационных мероприятий со школьниками и их родителями» (должности ассистента, преподавателя, старшего преподавателя и доцента).

Фактически структура должностных обязанностей ППС, сложившаяся исторически и включающая учебную, учебно-методическую, научно-исследовательскую, организационно-методическую и воспитательную работу, меняется. Меняется значимость отдельных трудовых функций.

Внедрение данного элемента ПС связано и с распределением учебной нагрузки по должностям ППС. Проблема связана с необходимостью одновременного соблюдения ФГОС ВО. Так, например, ОТФ «Преподавание по программам бакалавриата, специалитета, магистратуры и ДПП, ориентированным на соответствующий уровень квалификации» соответствует должности «доцент». Для должностей ассистента, преподавателя и старшего преподавателя предусмотрена ОТФ «Преподавание по программам бакалавриата и ДПП, ориентированным на соответствующий уровень квалификации». Это означает, что ассистенты, преподаватели и старшие преподаватели не могут вести занятия по образовательным программам специалитета (кроме преподавания дисциплин, не связанным непосредственно с освоением квалификации, например, физической культуры или иностранного языка). При этом ФГОС ВО специалитета требуют, как правило, только 60 \% уровня остепененности ППС. Возможно, частичный перевод не имеющих ученой степени старших преподавателей на должности доцентов, в соответствии с квалификационными требованиями ПС, может решить данную проблему, но вряд ли такие решения позитивно скажутся на качестве подготовки.

Внедрение ПС в этой части требует переработки должностных инструкций, положений о конкурсе ППС и ряда других локальных нормативных актов, внесения изменений в структуру индивидуального плана работы преподавателя.

3. Требования к необходимым знаниям и умениям по ТФ по должностям ППС. Этот элемент ПС может быть использован для разработки оценочных средств для проведения аттестации ППС, обязательное проведение которой в соответствии с законодательством РФ предусмотрено ПС в разделе «особые условия допуска к

\section{Baikal Research Journal}

электронный научный журнал Байкальского государственного университета 
работе». При этом в ПС педагога нет ни слова о конкурсном отборе, который является необходимым условием заключения трудового договора с ППС в соответствии с Трудовым кодексом РФ.

Профессиональный стандарт педагога не содержит формулировок компетенций современного преподавателя, наличие которых позволило бы более целенаправленно планировать их профессиональное развитие. Тем не менее, описание ОТФ, ТФ, знаний и навыков позволяют эти компетенции выделить и сформулировать. Так, на основе анализа ПС педагога Н. А. Гетман, В. В. Котенко и Е. Н. Котенко выделяют три укрупненные компетенции современного преподавателя: научно-педагогическую, организационно-педагогическую и психолого-педагогическую [12]. Анализ требований профессионального стандарта педагога в разрезе данных компетенций позволяет сформулировать ряд проблем:

1. Научно-педагогическая компетенция может быть признана исключительно важной для профессорско-преподавательского состава, так как только преподаватель-исследователь может помочь сформировать исследовательские компетенции обучающихся. При этом следует отметить, что в описании трудовых функций в ПС педагога отсутствует собственно научно-исследовательская работа (НИР), традиционно являющейся важной частью деятельности преподавателя высшей школы. Так, ЕКС предусматривает участие всех ППС в научно-исследовательской работе кафедры, факультета, вуза, а по должности профессора - руководство самостоятельным научным направлением. В то же время, в ПС в требования к опыту практической работы ППС включены «систематические занятия научной деятельностью, соответствующей направленности (профилю) образовательной программы и (или) преподаваемому учебному курсу, дисциплине (модулю)». Возможно, это означает, что преподаватели должны осуществлять НИР в рамках грантов и хоздоговорных тем на основе совмещения должностей (например, в соответствии с ПС «Специалист по НИОКР»). По должности профессора для реализации трудовых функций по руководству подготовкой аспирантов по индивидуальному учебному плану ПС регламентирует наличие публикаций в ведущих отечественных и (или) зарубежных рецензируемых научных журналах и изданиях и (или) представления на национальных и международных конференциях результатов научно-исследовательской (творческой) деятельности, соответствующей области исследований аспиранта. Таким образом, НИР выводится из структуры трудовых функций преподавателя высшей школы, но ее результаты рассматриваются в качестве квалификационных требований. По всем должностям ППС предусматривается руководство научно-исследовательской и проектной деятельностью обучающихся, а для реализации этих функций преподаватель должен систематически участвовать в НИР.

2. В качестве проблемного вопроса следует отметить реализацию психолого-педагогической компетенции, которая подробно представлена в профессиональном стандарте (выделены трудовые функции «Создание педагогических условий развития группы (курса) обучающихся по программам ВО», «Социально-педагогическая поддержка обучающихся по программам ВО в образовательной деятельности и профессионально-личностном развитии»). В описании трудовых функций значительное место уделено педагогическому сопровождению обучающихся, использованию современных педагогических технологий и пр., имеются требования к психолого-педагогическим знаниям и навыкам преподавателя вуза. При этом в ПС отсутствуют требования к наличию у ППС педагогического образования, профессиональной переподготовки (в отличие от преподавателей по программам среднего профессионального образования) или повышения квалификации в данной области. На наш взгляд, это явное противоречие.

\section{Baikal Research Journal}

электронный научный журнал Байкальского государственного университета 
Противоречивость принятого профессионального стандарта педагога отмечается И. А. Обыночным, который указывает, что в нем описаны не все трудовые функции (основные виды деятельности), в частности отсутствуют работа с работодателями с целью корректировки образовательных программ, обеспечение качества всех элементов учебного процесса и др., а имеющиеся формулировки с трудом поддаются интерпретации в контексте разделения управленческих и исполнительских функций по отдельным должностям ППС [13].

Необходимо отметить, что с введением профессионального стандарта «Педагог профессионального обучения, профессионального образования и ДПО» действие ЕКС не отменяется. Для полного перехода вуза на работу по профессиональным стандартам должны быть разработаны и утверждены ПС по всем должностям штатного расписания образовательного учреждения. Однако процесс их разработки затягивается. Так, в соответствии с приказом Минобразования и науки РФ от 27 мая 2015 г. № 536, ПС «Руководитель образовательной организации высшего образования, профессиональной образовательной организации и организации ДПО» должен был быть разработан в 2015 г., апробирован в 2016 г. и применен с 2018 г. Данный стандарт до сих пор не утвержден. Возникает проблема определения трудовых функций и требований к квалификации заведующих кафедрами и деканов. В настоящее время, в соответствии с Номенклатурой должностей педагогических работников организаций, осуществляющих образовательную деятельность, должностей руководителей образовательных организаций, утвержденной Постановлением Правительства РФ от 8 августа 2013 г. № 678, эти должности отнесены к профессорско-преподавательскому составу. Профессиональный стандарт педагога не описывает данные должности, и структурирование их трудовых функций станет возможным лишь после принятия профессионального стандарта руководителя образовательной организации.

Сложилась ситуация, когда ЕКС содержит требования по всем должностным позициям вуза, а ПС разработаны не по всем должностям. Минтруд РФ информирует, что в перспективе планируется замена ЕКС и ЕТКС профессиональными стандартами и отдельными отраслевыми требованиями к квалификации работников, утверждаемыми законодательными и иными нормативными правовыми актами, но такая замена будет происходить в течение достаточно долгого периода ${ }^{1}$. Соответственно, очень важно понимать, когда необходимо завершить внедрение профессионального стандарта педагога. В настоящее время и процедура государственной аккредитации образовательных программ, и контрольно-надзорная деятельность учредителя основаны на проверке соответствия требований и распределения трудовых функций в соответствии с ЕКС. Тогда смягчение требований к ППС в соответствии с профессиональным стандартом - это серьезный риск получения вузом замечаний и предписаний.

Для организаций государственного сектора принято постановление Правительства РФ от 27 июня 2016 г. № 584 ${ }^{2}$, в соответствии с которым в государственных вузах профессиональные стандарты в части требований к квалифика-

${ }^{1}$ О профессиональных стандартах : письмо М-ва труда и соц. защиты РФ от 6 июля 2016 г. № 14-2/ООГ-6465 // СПС «КонсультантПлюс».

${ }^{2}$ Об особенностях применения профессиональных стандартов в части требований, обязательных для применения государственными внебюджетными фондами Российской Федерации, государственными или муниципальными учреждениями, государственными или муниципальными унитарными предприятиями, а также государственными корпорациями, государственными компаниями и хозяйственными обществами, более пятидесяти процентов акций (долей) в уставном капитале которых находится в государственной собственности или муниципальной собственности : постановление Правительства РФ от 27 июня 2016 г. № 584 // Там же.

\section{Baikal Research Journal}

электронный научный журнал Байкальского государственного университета 
ции, необходимой работнику для выполнения определенной трудовой функции, применяются поэтапно на основе утвержденных указанными организациями с учетом мнений представительных органов работников планов по организации применения профессиональных стандартов. Реализация мероприятий планов необходимо завершить не позднее 1 января 2020 г. При этом органы и организации, осуществляющие полномочия учредителей указанных организаций, а также осуществляющие контроль и координацию деятельности таких организаций, обеспечивают внесение изменений в установленном порядке в соответствующие нормативные правовые акты и документы, требующие учета положений профессиональных стандартов, подлежащих применению. Данное постановление регламентирует введение в действие всех профессиональных стандартов в государственных организациях, в том числе и профессионального стандарта «Педагог профессионального обучения, профессионального образования и ДПО», только в части требований к квалификации. Это означает, что до 1 января 2020 г. переход к профессиональному стандарту педагога в части требований к квалификации ППС в государственных вузах должен быть завершен. При этом никаких «изменений в установленном порядке в соответствующие нормативные правовые акты и документы, требующие учета положений профессиональных стандартов, подлежащих применению» Минобрнауки РФ пока не внесено.

Помимо Трудового кодекса РФ, необходимость учета профессиональных стандартов при определении требований к ППС зафиксирована в ФЗ «Об образовании» (ст. 46): право на занятие педагогической деятельностью имеют лица, имеющие среднее профессиональное или высшее образование и отвечающие квалификационным требованиям, указанным в квалификационных справочниках, и (или) профессиональных стандартах. Таким образом, регламентирована возможность использования и ЕКС, и ПС одновременно, или использование одного из этих документов при определении квалификационных требований к ППС. Очевидно, что до 2020 г. в ФЗ «Об образовании в РФ» должны быть внесены изменения относительно использования для определения квалификационных требований к ППС только профессиональных стандартов.

Для работы образовательной организации высшего образования принципиально важным является соблюдение квалификационных требований к ППС, указанных в ФГОС ВО. Проекты ФГОС $3++$ содержат п. 4.4.2, в соответствии с которым «Квалификация научно-педагогических работников Организации должна отвечать квалификационным требованиям, указанным в квалификационных справочниках, и (или) профессиональным стандартам (при наличии)». Таким образом, как и ФЗ «Об образовании в РФ», ФГОС ВО в настоящее время допускает одновременное использование ЕКС и ПС.

Проведенный анализ показал наличие ряда достаточно серьезных трудностей внедрения профессионального стандарта педагога в практику управления педагогическими работниками, отнесенными к профессорско-преподавательскому составу в российских вузах. Внедрение профессионального стандарта педагога сопряжено с рядом методических проблем и проблем нормативного регулирования, которые не могут быть решены на уровне отдельного университета. Кроме того, следует учитывать, что переход к этому стандарту повысит уровень публичной формализации деятельности преподавателей, оказывающей, по мнению исследователей, скорее негативное влияние на характеристики эффективности работы вузов [14]. Соответственно, вопросы внедрения профессионального стандарта педагога в отношении ППС нуждаются в дальнейшей правовой, методической и организационной проработке.

\section{Baikal Research Journal}

электронный научный журнал Байкальского государственного университета 


\section{Список использованной литературы}

1. Былков В. Г. Трансформация системы квалификаций на основе создания профессиональных стандартов / В. Г. Былков // Известия Байкальского государственного университета. - 2014. - № 1 (93). - С. 67-73.

2. Лушникова М. Право на профессиональное образование и обучение: проблема реализации в современных условиях [Электронный ресурс] / М. Лушникова, А. Лушников // Управление персоналом. - 2007. - № 7. - Режим доступа: http://www.top-personal.ru/ issue.html?1083.

3. Профессиональный стандарт педагога профессионального обучения: подходы к разработке / Г. М. Романцев, В. А. Федоров, И. В. Осипова, О. В. Тарасюк // Вестник Учебно-методического объединения по профессионально-педагогическому образованию. - Екатеринбург : Изд-во Рос. гос. проф.-пед. ун-та, 2012. - Вып. 1 (46). - С. 14-25.

4. Воеводина С. С. Профессиональный стандарт «преподаватель» в менеджменте высшего образования / С. С. Воеводина, Н. Г. Фомиченко // Актуальные вопросы физической культуры и спорта. - Краснодар : Кубан. гос. ун-т физ. культуры, спорта и туризма, 2015. - Вып. 17. - С. 140-145.

5. Завиша Д. Ю. Педагог в современном инновационном социокультурном пространстве, его профессиональный стандарт и выбор направлений совершенствования структуры и содержания / Д. Ю. Завиша // Вестник ТОГИРРО. - 2015. - № 1 (31). - С. 78-82.

6. Крылов А. Н. Некоторые аспекты применения профессионального стандарта «Педагог профессионального обучения, профессионального образования и дополнительного профессионального образования» / А. Н. Крылов // Сборник трудов по проблемам дополнительного профессионального образования. - М. : Междунар. ассоц. проф. доп. образования, 2016. - Вып. 29. - С. 104-112.

7. Фролова С. Л. Профессиональный стандарт и профессиональный идеал соотношение понятий / С. Л. Фролова // Academia. Педагогический журнал Подмосковья. - 2015. № 2. - С. 23-26.

8. Батракова И. С. Развитие профессиональной компетентности профессорско-преподавательского состава в условиях реформирования высшего образования / И. С. Батракова, В. А. Бордовский // Человек и образование. - 2009. - № 3 (20). - C. 44-49.

9. Факторович А. А. Преподаватель вуза как гарант качества образования / А. А. Факторович // Вестник Московского городского педагогического университета. Сер.: Педагогика и психология. - 2011. - № 4. - С. 17-24.

10. Гребенникова О. М. Информационно-методическое сопровождение профессионального развития педагога в процессе внедрения профессионального стандарта педагога / О. М. Гребенникова // Академический вестник. Вестник Санкт-Петербургской академии постдипломного образования. - 2015. — № 3 (29). — С. 91-95.

11. Научно-педагогическая деятельность преподавателя технического вуза в соответствии с требованиями профессионального стандарта / В. А. Куклев, Т. М. Егорова, Э. В. Мусифуллина, Э. Б. Герасимова // Электронное обучение в непрерывном образовании : материалы 3-й Междунар. науч.-практ. конф. Ульяновск, 13-15 апр. 2016 г. Ульяновск : Ульян. гос. техн. ун-т, 2016. - Вып. 1 (3). — С. 274-278.

12. Гетман Н. А. Подготовка преподавателя вуза к профессиональной деятельности в соответствии с современными профессиональными стандартами / Н. А. Гетман, В. В. Котенко, Е. Н. Котенко // Современные наукоемкие технологии. - 2016. — № 9-3. C. 490-494.

13. Обыночный И. А. Сравнительный анализ профессионального стандарта «преподаватель высшего образования» и компетентностных моделей педагогов / И. А. Обыночный // Известия Института инженерной физики. - 2016. - Т. 3, № 41. - С. 96-98.

14. Карлина О. А. Отражение модели преподавателя современного вуза в содержании профессионального стандарта / О. А. Карлина // Наука 21 века: вопросы, гипотезы, ответы. - 2014. - Т. 2, № 2. - С. 54-57.

\section{References}

1. Bylkov V. G. Transformation of system of qualifications on the basis of developing professional standards Izvestiya Irkutskoi gosudarstvennoi ekonomicheskoi akademii = Bulletin of Irkutsk State Academy of Economics, 2014, no. 1 (93), pp. 67-73. (In Russian).

\section{Baikal Research Journal}


2. Lushnikova M., Lushnikov A. Right for professional education and teaching: problem of implementation in current environment. Upravlenie personalom $=$ Human Resources Management, 2007, no. 7. Available at: http://www.top-personal.ru/issue.html?1083. (In Russian).

3. Romantsev G. M., Fedorov V. A., Osipova I. V., Tarasyuk O. V. Professional standard of conveyor of knowledge in professional education: approaches to development. Vestnik Uchebno-metodicheskogo ob"edineniya po professional'no-pedagogicheskomu obrazovaniyu. Bulletin of Education and Methodical Association for Professional and Teacher Education]. Yekaterinburg, Russian State Vocational Pedagogical University Publ., 2012, iss. 1 (46), pp. 14-25. (In Russian).

4. Voyevodina S. S., Fomichenko N. G. Professional standard of «faculty member» in university management. Aktual'nye voprosy fizicheskoi kul'tury i sporta [Topical issues of physical education and sport]. Krasnodar, Kuban State University of Physical Education, Sport and Tourism Publ., 2015, iss. 17, pp. 140-145. (In Russian).

5. Zavisha D. Yu. Conveyor of knowledge in current innovative socio-cultural space, its professional standard and choice of directions of improving the structure and content. Vestnik TOGIRRO = Bulletin of Tyumen Regional State Institute of Regional Education Development, 2015, no. 1 (31), pp. 78-82. (In Russian).

6. Krylov A. N. Some aspects of applying the professional standard «Conveyor of knowledge of professional teaching, professional education and additional professional education". Sbornik trudov po problemam dopolnitel'nogo professional'nogo obrazovaniya [Collection of works on problems of additional professional education]. Moscow, International Association of Professional Further Education Publ., 2016, no. 29, pp. 104-112. (In Russian).

7. Frolova S. L. Professional standards and professional ideal: value concepts. Academia. Pedagogicheskii zhurnal Podmoskov'ya = Academia. Pedagogical Journal of Moscow Region, 2015, no. 2, pp. 23-26. (In Russian).

8. Batrakova I. S., Bordovsk V. A. Developing professional competence of faculty members in terms of reforming university education. Chelovek $i$ obrazovanie = Man and Education, 2009, no. 3 (20), pp. 44-49. (In Russian).

9. Faktorovich A. A. Faculty member as a guarantor of education quality. Vestnik Moskovskogo gorodskogo pedagogicheskogo universiteta. Seriya Pedagogika $i$ psikhologiya = Bulletin of Moscow City Teachers University. Series: Education Science and Psychology, 2011, no. 4, pp. 17-24. (In Russian).

10. Grebennikova O. M. Information and methodical support of professional development of conveyor of knowledge in the process of introducing professional standard of conveyor of knowledge. Akademicheskii vestnik. Vestnik Sankt-Peterburgskoi akademii postdiplomnogo obrazovaniya = Academic Bulletin, 2015, no. 3 (29), pp. 91-95. (In Russian).

11. Kuklev V. A., Yegorova T. M., Musifullina E. V., Gerasimova E. B. Scientific and educational activity of technical university faculty member in accordance with requirements of professional standards. Elektronnoe obuchenie v nepreryvnom obrazovanii. Materialy 3-i Mezhdunarodnoi nauchno-prakticheskoi konferentsii. Ul'yanovsk, 13-15 aprelya 2016 g. [E-learning in continuous education. Materials of the $3^{\text {rd }}$ International Research Conference. Ulyanovsk, April 13-15, 2016]. Ulyanovsk, 2016, no. 1 (3), pp. 274-278. (In Russian).

12. Getman N. A., Kotenko V. V., Kotenko E. N. Training faculty members for professional work in accordance with current professional standards. Sovremennye naukoemkie tekhnologii = Modern High Technologies, 2016, no. 9-3, pp. 490-494. (In Russian).

13. Obynochny I. A. Comparative analysis of the professional standard «Faculty member of higher education" and competency-based models of conveyors of knowledge. Izvestiya Instituta inzhenernoi fiziki = Bulletin of Institute of Engineering Physics, 2016, vol. 3, no. 41, pp. 96-98. (In Russian).

14. Karlina O. A. Reflection of university professor model in the content of professional standard. Nauka 21 veka: voprosy, gipotezy, otvety = 21st Century Science: Questions, Hypotheses, Answers, 2014, vol. 2, no. 2, pp. 54-57. (In Russian).

\section{Информация об авторах}

Озерникова Татьяна Георгиевна - доктор экономических наук, профессор, кафедра экономики труда и управления персоналом, проректор по учебной работе и международной деятельности, Байкальский государственный университет, 664003, г. Иркутск, ул. Ленина, 11, е-mail: ozernikova@mail.ru.

\section{Baikal Research Journal}

электронный научный журнал Байкальского государственного университета 
Еловенко Денис Александрович - кандидат технических наук, доцент, кафедра конструирования и стандартизации в машиностроении, Иркутский национальный исследовательский технический университет, 664074, г. Иркутск, ул. Лермонтова, 83, e-mail: elovenko03@gmail.com.

\section{Authors}

Tatiana G. Ozernikova - Doctor habil. (Economics), Professor, Chair of Labour Economy and Personnel Management, Vice-rector for Curriculum Development and International Activity, Baikal State University, 11 Lenin St., 664003, Irkutsk, Russian Federation; e-mail: ozernikova@mail.ru.

Denis A. Elovenko - PhD in Engineering, Associate Professor, Chair of Design and Standardization in Machine Building, Irkutsk National Research Technical University, 83 Lermontov St., 664074, Irkutsk, Russian Federation; e-mail: elovenko03@gmail.com.

\section{Библиографическое описание статьи}

Озерникова Т. Г. Проблемы внедрения профессионального стандарта в систему трудовой деятельности профессорско-преподавательского состава вузов / Т. Г. Озерникова, Д. А. Еловенко // Baikal Research Journal. - 2017. - T. 8, № 2. - DOI: 10.17150/24116262.2017.8(2).32.

\section{Reference to article}

Ozernikova T. G., Elovenko D. A. Problems of introducing the professional standard in the labor activity system for university faculty members. Baikal Research Journal, 2017, vol. 8, no. 2. DOI: 10.17150/2411-6262.2017.8(2).32. (In Russian).

\section{Baikal Research Journal}

